\title{
Hyaluronan in the Skin and Its Correlation with Dermatopathology
}

\author{
皮膚のヒアルロン酸 : 各種病態との関連
}

\author{
Kon, Atsushi \\ Department of Nutrition, Faculty of Health Science, Aomori University of Health and Welfare, \\ Aomori, Aomori 030-8505, Japan \\ FAX: 81-17-765-4009,E-mail: a_kon@auhw.ac.jp
}

(Received on March 7, 2010, accepted on April 29, 2010)

Key Words: hyaluronan, skin, wound healing, aging, melanoma, metastasis

\begin{abstract}
The skin is an important organ that not only covers the body but also performs various functions, such as temperature regulation, respiration, sensory functions, and immune functions. Therefore, if the functions of the skin are lost, the entire body would be affected and we would be unable to live. Recent studies have shown that hyaluronan is an important factor that maintains skin homeostasis by regulating skin development, proliferation, differentiation, regeneration, and anti-aging. On the other hand, it has been revealed that hyaluronan is also a risk factor that facilitates proliferation and metastasis of malignant skin tumors. Accordingly, it is expected that if the expression of hyaluronan in the skin can be artificially and freely regulated, it should be possible to maintain not only a person's skin health but also their general health. In this review, I outline the importance of hyaluronan, focusing on the correlation between skin hyaluronan and the pathophysiology of the skin.
\end{abstract}

\section{A. Introduction}

The skin is an organ that not only covers the body but also performs various functions, such as temperature regulation, respiration, sensory functions, and immune functions. In particular, the immune functions are extremely important functions because they are the first line of protection of the body against the actions of harmful factors present in the external world, such as the onset of infectious diseases due to bacterial or viral invasion of the body, or carcinogenesis due to ultraviolet radiation. If these functions of the skin are lost, harmful factors would easily pass through it, thus significantly affecting the organs in the deeper parts of the body. Therefore, maintaining a normal skin function is very important, not only for a person's skin health but also for their general health. However, various factors, such as aging and trauma, cause a gradual decline in the skin function.

Hyaluronan, which is abundant in the extracellular matrix of the skin, regulates skin development, proliferation,
要 約

皮膚は生体を被うだけではなく、体温の調節、呼吸、感 覚、免疫などの様々な機能を有する重要な臟器である。従って、 皮膚の機能が失われてしまえば、生体全体に影響を生じ、我々 は生きて行くことができない。最近、ヒアルロン酸は皮膚の 発生、増殖、分化、再生、抗加齢などを制御し、皮膚のホメ オスタシスを維持する上で非常に重要であることが証明され た。その一方で、皮膚の悪性腫瘍の増殖や転移を促進する危 険因子であることも明らかになった。従って、皮膚のヒアル ロン酸の発現を自由自在に制御できれば、皮膚のみならず全 身の健康を維持することができると考えられる。本総説では、 皮膚に扔けるヒアルロン酸と皮膚疾患・病態との関連を中心 に紹介し、ヒアルロン酸の重要性について言及する。

A. はじめに

皮膚は単に生体を被うだけではなく、体温の調節、呼吸、 触覚、痛覚、温冷覚などの各種感覚、そして免疫など、多く の機能を有する臟器である。特に免疫は、外界に存在する有 害因子の作用、例えば、細菌やウィルスの生体内への侵入に よる感染症の発症や、紫外線による発癌など、から生体を真っ 先に防御してくれるため、非常に重要な機能である。もし、 これらの皮膚の機能が失われてしまえば、有害因子は皮膚を 容易に通過し、媣部に存在する臟器にも多大な影響を及ぼす。 従って、皮虚の機能を正常に維持することが、皮膚のみなら ず全身の健康にとって非常に重要なことである。しかし、加 齢の過程で生じる老化、外傷などの不慮の損傷など、様々な 原因によって皮膚の機能は次第に低下してゆく。

皮膚の細胞外マトリックスに豊富に存在するヒアルロン 酸は、皮膚の発生、増殖、分化、再生、抗加齢などを制御し、 
differentiation, regeneration, and anti-aging, thereby maintaining skin homeostasis $(1,2)$. On the other hand, hyaluronan is also a risk factor that facilitates proliferation and metastasis of malignant skin tumors (3-6). As such, hyaluronan regulates the functions of the skin in various ways. Accordingly, if it becomes possible to regulate the hyaluronan expression in the body intentionally and freely, it is expected that it would be possible to maintain not only a person's skin health but also their general health.

In this review, I outline the correlation between hyaluronan and the pathophysiology of the skin. I will do this by focusing on the correlation between hyaluronan and wound healing, particularly scarless wound healing, when the skin heals from damage without scar formation, aging, and the proliferation and metastasis of malignant skin tumors.

\section{B. Hyaluronan Expressed in Skin}

Hyaluronan, which is composed of repeated $\beta-1,4-$ glucuronic acid-1,3- $N$-acetylglucosamine disaccharide units, is a non-sulfated glycosaminoglycan with a molecular weight of over 1,000,000 Da (Fig. 1) (7). The amount of hyaluronan present in the skin is equivalent to $50 \%$ or more of the total amount of hyaluronan in the body $(8,9)$. Hyaluronan is abundant in the extracellular matrix of the epidermis and dermis that comprise the skin (Fig. 2). Epidermal keratinocytes, melanocytes, and dermal fibroblasts are the major cells that synthesize hyaluronan. The cell membrane of each cell contains 3 types of hyaluronan synthases (HAS) (HAS-1, HAS-2, and HAS-3) that synthesize hyaluronan (10-13). Accordingly, under a microscope, abundant hyaluronan distribution surrounding the cells, or in other words a hyaluronan-rich matrix, is observed (Fig. 1) (14, 15).
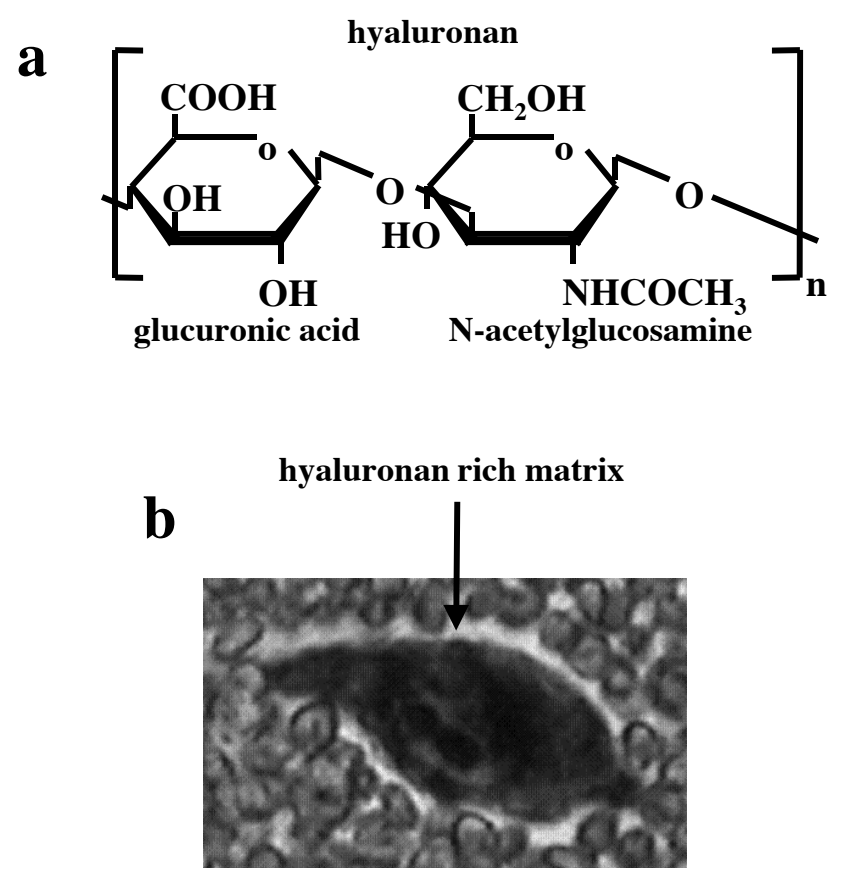

皮膚のホメオスタシスを維持する上で非常に重要な物質であ ることが証明されている $(1,2)$ 。その一方で、ヒアルロン酸は 皮膚悪性腫瘍の増殖や転移を促進する危険因子でもある (3-6)。 この様に、ヒアルロン酸は、良きにつけ悪しきにつけ、皮膚 の機能を様々な方向に制御しうる物質である。従って、生体 内におけるヒアルロン酸の発現を、人為的に自由自在に制御 することが可能になれば、皮膚、そして全身の健康はいつま でも維持できると考えられる。

本総説では、ヒアルロン酸が皮膚の疾患や病態にどの様に 関わっているのかを概説する。創傷治癒、特に、皮膚がひど く傷ついても決して瘏痕を残さず治癒する胎仔創傷治癒機構 (scarless wound healing) との関係や、老化、覀性腫瘍の増殖 · 転移との関係を中心に紹介する。

\section{B. 皮膚で発現するヒアルロン酸}

グルクロン酸と $N$ - アセチルグルコサミンの 2 糖の繰り返 し構造を有するヒアルロン酸は、分子量が 100 万を超える高 分子の非硫酸化グリコサミノグリカンである (図 1)(7)。大量の ヒアルロン酸が皮膚に存在しており、生体に存在する全ヒア ルロン酸の $50 \%$ 以上にも相当する $(8,9)$ 。皮膚は外界の側から 表皮、真皮及び皮下組織の 3 層で構成されるが、表皮と真皮 の細胞外マトリックスにヒアルロン酸は豊富に存在している ( 図 2)。表皮の角化細胞とメラニン産生細胞(メラノサイト)、 真皮の線維芽細胞は、いずれもヒアルロン酸を生合成する代 表的な細胞である。各細胞の細胞膜には、膜貫通型酵素であ る 3 種類のヒアルロン酸合成酵素 (HAS1、HAS2、HAS3) が存 在し、細胞膜上でヒアルロン酸を生合成している (10-13)。従っ て、顕微鏡で観察すると、細胞を取り囲むようにヒアルロン 酸が豊富に存在している像、すなわちヒアルロン酸リッチマ トリックスが観察される (図 1)(14, 15)。後に、このヒアルロン
Fig. 1. Composition of hyaluronan (a) and a microscopic view of hyaluronan rich matrix (b). 


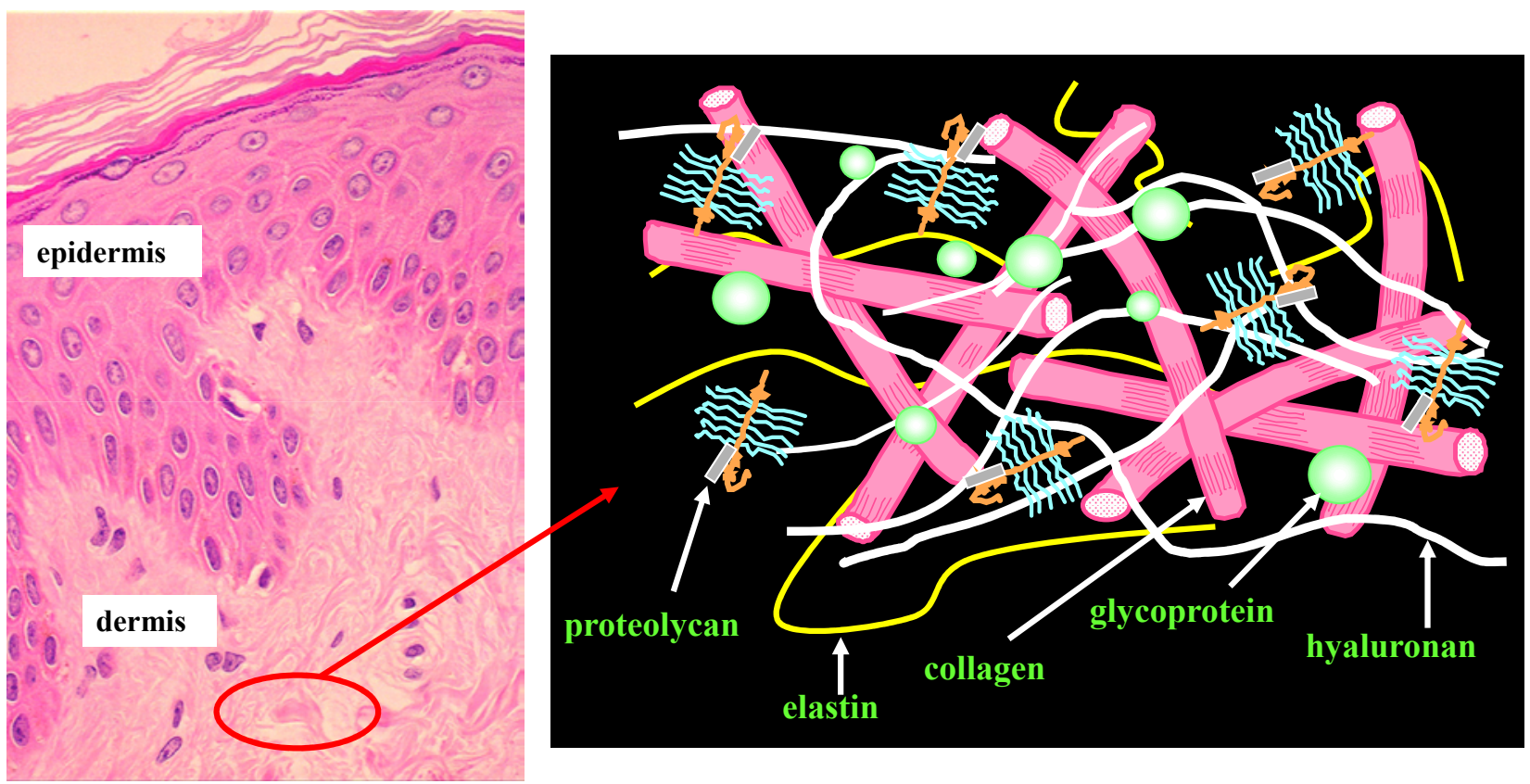

Fig. 2. Schematic illustration of the extracellular matrix structure of the skin.

Subsequently, hyaluronan moves toward the extracellular matrix and regulates the functions and pathophysiology of the skin.

\section{Correlation between Hyaluronan Expression and Scarless Wound Healing}

In adult mammals, with some exceptions such as the liver, organs do not regenerate once damaged. Similarly, the skin heals with scar formation once it is deeply injured below the dermal level. This wound healing mechanism is referred to as postnatal wound healing. In the scarred area, the number of collagen fibers increase and become irregularly arranged, resulting in fibrosis. In addition, the numbers of elastic fibers decrease and diminish. As such, the skin elasticity declines, the skin is hardened, and normal functions are lost. On the other hand, in the fetal phase of mammals, scarless wound healing, by which the skin regenerates completely, occurs. Even if the skin is severely damaged, the skin perfectly regenerates without scar formation (16). In rats, because scarless wound healing occurs until the 16th day of the fetal period, no scars are formed in this period. After the 18th day of the fetal period, scarless wound healing is diminished, resulting in the formation of scars (17). For mice, scarless wound healing changes to postnatal wound healing between the 13th and 14th day of the fetal period for the epidermis and between the 16th and 17th day of the fetal period for the dermis (18). In monkeys, wounds heal without scar formation until the 75th day of the fetal period; however, scars are formed after the 85th day (19).
酸が、細胞外マトリックスの方に移動し、先に述べた皮膚の 各種機能や病態の形成を制御することになる。

C. ヒアルロン酸と胎仔創傷治癒機構との関係

哺乳類動物の成獣では、肝臟などの例外はあるが、臟器 が傷つくと決して再生されない。皮膚も同様であり、真皮レ ベルを超える深い傷を負うと、瘏痕を残して治癒することに なる。この創傷治癒機構を成獣創傷治癒機構と言う。瘕痕の 部分では、コラーゲン線維が増生し、しかも不規則に配列し て線維化する。また、弾性線維は減少或いは消失してしまう。 その結果、皮膚は弾力性にそしく、また硬くなり、正常な機 能は失われてしまう。一方、哺乳類動物の胎生期には、皮膚 が完全に再生できる胎仔創傷治癒機構 (scarless wound healing) が存在する。この機構では、皮膚はひどく傷ついても瘕 痕を全く残さず完全に再生される (16)。ラットでは、胎生 16 日まで胎仔創傷治癒機構が存在するため瘏痕は形成されない。 しかし、胎生 18 日以降では胎仔創傷治癒機構が無くなり、躲 痕を形成するようになる (17)。マウスでは、表皮は胎生 13 日 と 14 日の間、真皮は胎生 16 日と 17 日の間に胎仔創傷治癒機 構が成獣創傷治癒機構に移行する時期が存在する (18)。サルで は、胎生 75 日には傷は瘏痕を残さず治癒するが、85 日以降で は痒痕を形成して治癒する (19)。 
One of the characteristics of scarless wound healing is that hyaluronan in the skin is present for a longer period and at a higher concentration compared to postnatal wound healing, and it is believed that this is one of the reasons why scars are not formed. Indeed, when a wound is created in the skin of a fetal rat, hyaluronan is immediately and excessively synthesized and slowly degraded. On the other hand, for postnatal wound healing, hyaluronan is synthesized relatively early but also quickly degraded (20). In addition, in organ cultures of the legs of adult mice in highconcentration hyaluronan solutions, scar formation on the skin is moderate and the wound is immediately closed (21). When hyaluronidase (Hyal), a hyaluronan-degrading enzyme, is administered to injured skin to decrease the hyaluronan content, scar formation becomes prominent (22). We also found that, in hyaluronan knockdown mice (described in detail below), scar formation becomes prominent. Furthermore, it is well known that scars and wrinkles can be healed by injecting hyaluronan into the skin.

Kennedy et al. reported that in scarless wound healing, dermal fibroblasts biosynthesize a large amount of hyaluronan; however, the difference to the amount of hyaluronan in postnatal wound healing is small. In addition, no differences were observed in the expression level of HAS genes between the mechanisms of scarless wound healing and postnatal wound healing (23). However, the reactivity of dermal fibroblasts to inflammatory cytokines [tumor necrosis factor $\alpha$ (TNF- $\alpha$ ), interleukin $1 \beta$ (IL-1 $\beta$ )] is different in each mechanism. TNF- $\alpha$ and IL-1 $\beta$ increase the hyaluronan biosynthesis in both scarless wound healing and postnatal wound healing; however, the hyaluronan biosynthesis increased to a greater extent in scarless wound healing The expression of the HAS- 1 gene is facilitated by both TNF- $\alpha$ and IL- $1 \beta$, whereas the expression of the HAS-3 gene is facilitated by TNF- $\alpha$ only; the promoting effect is stronger in postnatal wound healing (23). Since there have been no reports on the relationship between the expressions of Hyal genes and scarless wound healing, nothing definitive can be said. However, based on the fact that there is no difference in the expressions of HAS genes and the reactivity of inflammatory cytokines in hyaluronan biosynthesis and the expression of HAS genes are different between both wound healing mechanisms, the high hyaluronan content in the skin during scarless wound healing suggests, at the very least, that 2 mechanisms, one in which the expression of HAS genes is posttranscriptionally regulated and another one in which the expression of Hyal genes is suppressed, are present in scarless wound healing. In addition, it has recently been proven that hyaluronan suppresses the platelet functions of the fetus and it is believed that inflammation that occurs during skin damage suppresses the platelet functions, thus making it possible to
胎仔創傷治癒機構は、成獣創傷治癒機構に比較して、皮 膚のヒアルロン酸が長時間に渡り高濃度に維持されることが 特徵であり、これが痒痕を形成しない理由の一つと考えられ ている。事実、ラット胎仔の皮膚に傷を作成すると、ヒアル ロン酸は成獣よりも素早く且つ過剩に生合成され、しかも分 解は遅い。逆に、成獣創傷治癒機構では、ヒアルロン酸は比 較的速く生合成されるが、分解も早い (20)。また、高濃度のヒ アルロン酸溶液中で成獣マウスの脚を器官培養すると、皮膚 の㓔痕形成は軽度で、傷の閉鎖も速やかであった (21)。ヒアル ロン酸分解酵素のヒアルロニダーゼ(Hyal)を傷ついた皮膚に 投与してヒアルロン酸の含量を低下させると、瘏痕の形成は 著明になった (22)。我々も、マウスのヒアルロン酸合成をノッ クダウンしたところ (詳細は後述)、瘏痕の形成は明膫になる ことを見出している。また、ヒアルロン酸を皮膚に注入して 瘏痕やしわを治療することはよく知られたことである。

Kennedy らは、胎仔創傷治癒機構に扔ける真皮線維芽細 胞が、ヒアルロン酸を多量に生合成するが、成獣創傷治癒機 構に抢けるヒアルロン酸の量と比較した場合、差はさほど著 明では無いと報告している。また、HAS 遺伝子の発現量は両 方の機構において同程度であり (HAS-2>HAS-3>HAS-1)、差 は全く認めなかった(23)。しかし、真皮線維芽細胞に対する 炎症性サイトカイン (TNF- $a$ 、IL-1 $\beta$ ) の反応性は各機構に 拐いて異なっていた。TNF- $\alpha$ と IL-1 $\beta$ は、胎仔創傷治癒機 構及び成獣創傷治癒機構の両方の機構におけるヒアルロン酸 の生合成を促進するが、胎仔創傷治癒機構においてより強力 であった。HAS-1 遺伝子の発現は TNF- $\alpha$ と IL-1 $\beta$ の両方に よって、HAS-3 遺伝子の発現は TNF- $a$ よってのみ促進する が、その促進効果は成獣創傷治癒機構においてより強力であっ た (23)。Hyal 遺伝子の発現と胎仔創傷治癒機構との関係につ いての研究報告が無いために現時点で確定的なことは言えな いが、HAS 遺伝子の発現には差が無く、また、ヒアルロン酸 の生合成と HAS 遺伝子の発現に対する炎症性サイトカインの 反応性が両方の創傷治癒機構では異なることから、胎仔創傷 治癒機構における皮膚のヒアルロン酸含量が高值であること は、少なくとも、HAS 遺伝子が転写以降に修飾を受けること や、Hyal 遺伝子の発現が抑制されている、ことなどが胎仔創 傷治癒機構で生じている可能性を示唆している。また、最近、 ヒアルロン酸が胎仔の血小板の機能を抑制することも証明さ れ、皮膚が傷ついて炎症が生じる際に血小板の機能が抑制さ れ、そのために痏痕を形成しない可能性も考えられている(24)。 
heal wounds without forming scars (24).

The homeobox genes $M S X-1, M S X-2, P R X-2$, and $M O X-1$, which are essential for morphogenesis, are strongly expressed in scarless wound healing, thus suggesting that each gene is an important regulatory factor for scarless wound healing $(25,26)$. In addition, the expression of the homeobox gene $H O X B 13$ is low in scarless wound healing but high in postnatal wound healing. When the skin of a HOXB13 knockout mouse is damaged, the wound is quickly closed without scar formation. Furthermore, the skin of these mice contains abundant hyaluronan, which also strongly suggests that hyaluronan is an important regulatory factor in scarless wound healing (27).

The regulatory mechanisms underlying hyaluronanmediated scarless wound healing are still unknown and require further detailed analysis. In particular, it is important to analyze the timing of the transition from scarless wound healing to postnatal wound healing. It is expected that by identifying hyaluronan-related key factors that regulate the transition period, it will be possible to rapidly promote skin regenerative medicine without leaving scars and to completely treat skin damage that leaves scars, such as burns or trauma.

\section{Correlation between Hyaluronan Expression and Skin Aging}

Skin aging is classified into 2 types: intrinsic aging and photo-aging. Intrinsic aging of the skin is inevitable as in the cases of other organs, and it is strictly regulated by various factors such as aging-related genes, hormones, and active oxygen. It is clinically characterized by fine wrinkles, dryness, and thinning observed in the unexposed areas of the skin, such as the body trunk (28). Photo-aging refers to skin-specific aging that occurs under ultraviolet (UV) radiation. Two types of UV radiation that arrive at the surface of the earth, UVA and UVB, cause the degeneration of body components such as DNA, proteins, lipids, and carbohydrates of the skin, and change the level of expression of cytokines and growth factors, and thereby causing a decline in skin function. In addition, the degenerated components themselves acquire carcinogenicity, leading to the development of malignant skin tumors such as basal cell carcinoma, squamous cell carcinoma, and melanoma. Due to the loss of strength and elasticity of the skin, deep wrinkles, spots, and skin malignancies appear in exposed areas such as the face and dorsal surface of the hand $(28,29)$. As such, the clinical symptoms are different between intrinsic aging and photo-aging; however, each type of aging does not occur independently, and photo-aging occurs in addition to intrinsic aging.

In aged skin, particularly photo-aged skin, the hyaluronan content is significantly decreased. On the other hand, by injecting hyaluronan into this skin, the symptoms
ボディープランの決定などを含む形態形成に重要なホメ オボックス遺伝子の $M S X-1 、 M S X-2 、 P R X-2 、 M O X-1$ は、胎 仔創傷治癒機構において強く発現しており、この機構の重要 な制御因子であると考えられている $(25,26)$ 。また、ホメオボッ ク又遺伝子の $H O X B 13$ は、胎仔創傷治癒機構で発現が低く、 逆に成獣創傷治癒機構では高い。HOXB13 ノックアウトマウ スの皮膚に傷をつけると、傷の閉鎖は早く、㓔痕を生じなかっ た。しかも、このマウスでは、皮膚のヒアルロン酸の生合成

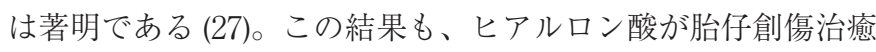
機構の重要な制御因子であることを示唆している可能性が考 えられる。

ヒアルロン酸による胎仔創傷治癒機構の詳細は依然とし て不明であるため、更なる解析が必要である。特に胎仔創傷 治癒機構から成獣創傷治癒機構への移行期の解析が重要であ ると思われ、移行期を制御するヒアルロン酸関連因子が同定 できれば、瘢痕を残さない皮膚の再生医療は急速に進み、熱傷、 外傷などの傷跡を残す皮膚疾患を完全に治療することが可能 になると期待される。

\section{D. ヒアルロン酸と皮膚の老化との関係}

皮膚の老化は生理的老化と光老化の 2 種類に分類される。 皮膚の生理的老化は、他の臓器の場合と同様に、避けること のできない老化であり、老化関連遺伝子、ホルモン、活性酸 素などの各種因子により厳密に制御されている。臨床的には、 体幹などの非露出部の皮膚に認める細かい小じわ、乾燥、菲 薄化を特徵とする $(28)$ 。光老化は皮膚に特異的な老化であり、 紫外線を浴びることで生じる老化である。地表に到達する 2 種類の紫外線の UVB と UVA は皮膚のDNA、タンパク質、 脂質、糖質などの生体の構成成分を変性し、サイトカインや 成長因子の発現も変化させ、その結果、皮膚の機能を低下さ せる。しかも、変性した成分自体は発癌性を持つようになり、 後に皮膚の悪性腫瘍が発生する。皮膚は強度と弾力を失うた め、顔面、手背などの露出部に、彫の深い㱀、しみ、そして、 基底細胞癌、有棘細胞癌、悪性黒色腫などの皮膚悪性腫瘍が 出現する $(28,29)$ 。この様に、生理的老化と光老化の臨床症状 は異なるが、各老化はそれぞれが独立して存在するのではな く、生理的老化の上に光老化が付加される。

老化、特に光老化した皮膚では、ヒアルロン酸の含量が 非常に減少している。一方、この皮膚にヒアルロン酸を注入 すると煼などの光老化の症状は消失する。これらのことから、 
of photo-aging, such as wrinkles, diminish. Therefore, hyaluronan is recognized as a substance that can suppress aging, or as an anti-aging substance. Some studies on the effect of UV radiation on the expression of hyaluronan have recently been published, and the regulatory mechanisms of hyaluronan for photo-aging have been gradually revealed.

Averbeck et al. performed UVB radiation of human epidermal keratinocytes $(\mathrm{HaCaT})$ and dermal fibroblasts and analyzed the expression of hyaluronan and hyaluronan-related genes shortly after irradiation, The expression of HAS genes in each cell was promoted 24 hours after irradiation. In addition, the expression of Hyal genes was not changed in HaCaT cells but was increased in dermal fibroblasts. Although the amount of hyaluronan production declined in both cells 3 hours after irradiation, it returned to normal levels in $\mathrm{HaCaT}$ cells after 24 hours, whereas it remained lower than normal in dermal fibroblasts. In addition, when human skin was irradiated with UVB, the hyaluronan content of the epidermis increased after 24 hours, whereas it decreased in the dermis (30). Calikoglu et al. irradiated the skin of mice with UVA or UVB and reported that after 2 hours, the hyaluronan production and the expression of the hyaluronan receptor, CD44, in the epidermis were suppressed but returned to normal after 24 hours (31).

Dai et al. repeatedly irradiated the skin of mice with UVB over a long period of time (3 times/week, 182 days) and demonstrated that the expression of HAS genes was suppressed, resulting in a marked decrease in the dermal hyaluronan content (32). They also reported that the expression of Hyal and CD44 did not vary. In addition, they demonstrated that the expression of transforming growth factor $\beta 1$ (TGF- $\beta 1$ ), which promotes the expression of HAS1 and HAS2, was also suppressed by UVB radiation, and considered this observation as one of the causes of the decrease in dermal hyaluronan content (32).

UV rays act on the hyaluronan expression in various ways depending on the irradiated area, amount, time, and duration after irradiation, indicating that the regulation of hyaluronan by UV rays is complicated. However, based on the fact that wrinkles are formed through exposure to UV irradiation over many decades, it is necessary to focus particularly on the results of repetitive UV irradiation experiments conducted over a long period of time. Therefore, long-term UV irradiation decreases the amount of hyaluronan production by suppressing the expression of HAS genes, and as a result, skin elasticity is lost. In addition, because an even stronger external force is imposed on the forehead and the corners of the eyes, it can be inferred that deep wrinkles are easily formed (Fig. 3).

Shortly after UV irradiation, the expression of hyaluronan and HAS genes in the skin is promoted. These results suggest that this is because the symptoms of acute
ヒアルロン酸は老化を抑制する物質、すなわちアンチエイジ ング物質として認識されている。最近、紫外線によるヒアル ロン酸の産生及びヒアルロン酸関連遺伝子の発現についての 研究が幾つか報告され、ヒアルロン酸による光老化の制御機 構は解明されつつある。

Averbeck らは、ヒト表皮角化細胞の細胞株 (HaCaT 細胞) と培養ヒト真皮線維芽細胞に紫外線 UVB を照射し、照射短時 間後におけるヒアルロン酸とヒアルロン酸関連遺伝子の発現 を解析している。照射 24 時間後、各細胞に打ける HAS 遺伝 子の発現は促進していた。また、Hyal 遺伝子の発現は HaCaT 細胞では変化していないが、真皮線維芽細胞では増加してい た。ヒアルロン酸の産生量は、照射 3 時間後には両細胞で低 下していたが、24 時間後に $\mathrm{HaCaT}$ 細胞では増加、真皮線維 芽細胞では依然低下したままであった。また、ヒトの皮膚に UVB を照射すると、照射 24 時間後に表皮のヒアルロン酸の 含量は増加し、真皮では逆に低下していた(30)。Calikogluらは、 マウスの皮膚にUVA 或いはUVB を照射し、照射 2 時間後で は表皮のヒアルロン酸の産生とヒアルロン酸レセプターCD44 の発現が抑制し、24 時間後に元の状態に戻ると報告している (31)。

Dai らはマウスの皮膚にUVB を長期間に渡って繰り返し 照射 (3 回/週、182 日間) し、HAS 遺伝子の発現が抑制され ること、そしてその結果、真皮のヒアルロン酸の含量が著明 に減少することを証明した。しかも、Hyal や CD44 の発現が 変動しないことを報告している(32)。また、HAS1、HAS2 の 発現を促進するTGF- $\beta 1$ の発現もUVBによって抑制される ことを証明し、このことも真皮に扔けるヒアルロン酸の含量 が減少する原因の一つであると考察している (32)。

ヒアルロン酸の発現に対する紫外線の作用は、照射部位、 照射量、照射時間、照射後の経過時間などで様々な挙動を示 し、複雑である。しかし、何十年もの長きに渡って紫外線を 浴びることで㱀が形成される事実から、紫外線の長期間に渡 る繰り返し照射実験の結果は特に重視する必要がある。従っ て、少なくとも、長期間に渡る紫外線照射はHAS 遺伝子の発 現を抑制することでヒアルロン酸の産生量を減少させ、その 結果、皮膚の弾力を失わせると考えられる。しかも、露出部 のうちでも、額、目じりなどは、常に強い外力がかかるため、 彫の深い皱が形成され易くなるのではないかと推察される (図 3)。

紫外線照射短時間後の皮膚では、ヒアルロン酸及び HAS 遺伝子の発現が促進していた。これは、紫外線による皮膚の 急性炎症の症状が依然として強いためにTNF- $a$ や IL-1 $\beta$ な 


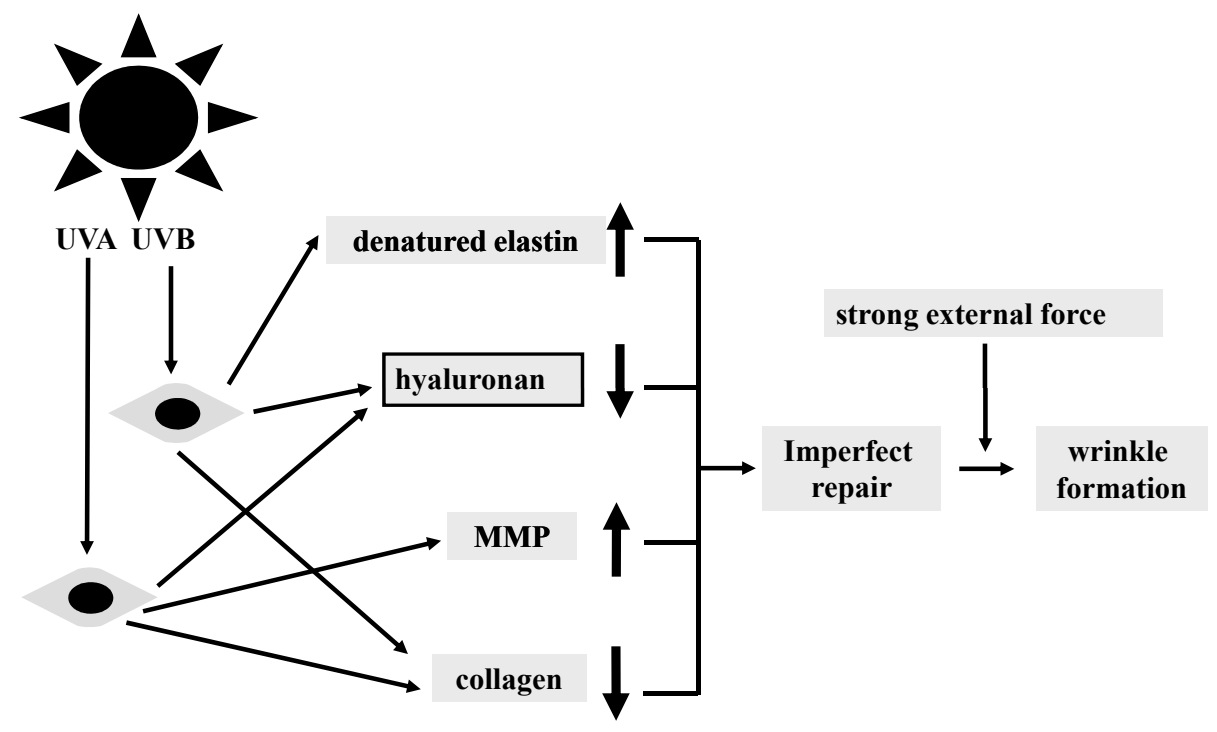

Fig. 3. Schematic representation of UV radiation-induced wrinkle formation. Long-term UV exposure decreases the expression of hyaluronan and collagen, whereas the expression of denatured elastin and matrix metalloproteinase increases, resulting in skin fragility. Additional and repeated external forces together with UV effects accelerate the formation of deep wrinkles, a clinical feature of photoaged skin.

inflammation of the skin caused by UV light are still severe, and the secretion of inflammatory cytokines such as TNF- $\alpha$ and IL- $1 \beta$ is therefore increased, the expression of HAS genes is temporally promoted, and, as a result, the rate of hyaluronan production may be increased.

\section{E. Correlation between Hyaluronan and Malignant Skin Tumor}

Hyaluronan is a risk factor that promotes the proliferation and metastasis of malignant tumors. The expression of hyaluronan and its receptor CD44 increases in many cases of malignant tumor, suggesting that it is significantly related to proliferation and metastasis.

4-Methylumbelliferone (MU) inhibits the binding of glucuronic acid, which is an HAS substrate, with another substrate of $\mathrm{N}$-acetylglucosamine, and thereby inhibits the synthesis of hyaluronan (Fig. 4) (33-35). We analyzed hyaluronan knockdown cells or animals generated by administering MU, as well as the effect of MU on the metastasis of malignant melanomas, which is one of the malignant tumors that develop in the skin at a high frequency. We demonstrated that, when treating the melanoma cells (B16F10 cells) of a mouse with MU, the hyaluronan-rich matrix on the cell surface is diminished, and the amount of hyaluronan translocating from there to the extracellular matrix is also decreased (Fig. 4) (15). However, MU did not affect the synthesis of components of the extracellular matrix such as other glycosaminoglycans, collagen, or laminin (15).

Next, we analyzed the effect of MU on the adhesion of
どの炎症性サイトカインの分泌が旮進し、HAS 遺伝子の発現 が一過性に促進、その結果、ヒアルロン酸の産生量が増加し ているのかも知れないと考えられる。

E. ヒアルロン酸と皮膚悪性腫瘍との関係

ヒアルロン酸は悪性腫瘍の増殖と転移を促進する危険因 子である。ヒアルロン酸及びヒアルロン酸レセプターCD44 の発現は悪性腫瘍で立進する場合が多く、これらが増殖と転 移に大きく関わると考えられている。

4-メチルウンベリフェロン (MU) は、ヒアルロン酸の生合 成の際に、HASの基質であるグルクロン酸が、もう一つの基 質である $N$ - アセチルグルコサミンに結合することを阻害し、 その結果ヒアルロン酸の生合成を阻害する(図 4) (33-35)。そ こで我々は、MUを細胞或いは動物に投与してヒアルロン酸 をノックダウンさせ、皮膚に高率に発症する悪性腫瘍である 悪性黒色腫の転移に対する影響を解析した。マウスの悪性黒 色腫細胞 (B16F10 細胞) を MU で処理すると、細胞表面の七 アルロン酸リッチマトリックスは消失し、しかも、ここから 細胞外マトリックスへと遊離するヒアルロン酸の量も減少す ることを証明した(図 4)(15)。しかし、MUはコンドロイチン 硫酸、デルマタン硫酸、ヘパラン硫酸などのグリコサミノグ リカンや、コラーゲン、ラミニンなどの他の細胞外マトリッ クスの成分の生合成には影響しなかった (15)。

次に、MUで処理した B16F10 細胞を培養血に撒き、接 
Fig. 4. MU-mediated inhibition of hyaluronan expression in melanoma cells. (a) The effect of MU on the formation of cell surface hyaluronan was analyzed by particle exclusion assay. When B16F10 cells were incubated without MU, a hyaluronanrich matrix could be observed, whereas it disappeared in the presence of MU. (b) B16F10 cells were incubated with various concentrations of MU for $48 \mathrm{~h}$, and the hyaluronan released into the culture medium was analyzed by ion-exchange HPLC. The amount of hyaluronan released into the culture medium was decreased in a dosedependent manner when MU was present.

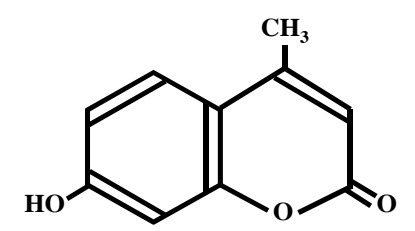

4- metylumbelliferone (MU)

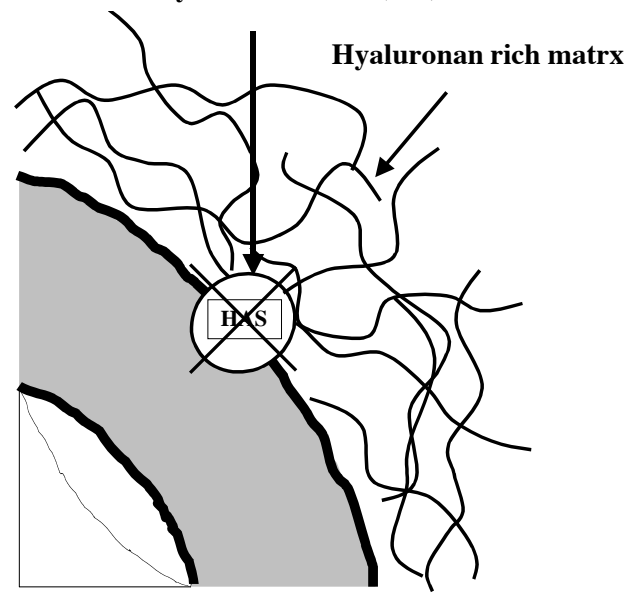

a

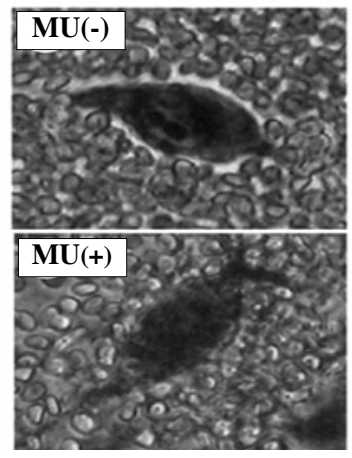

b

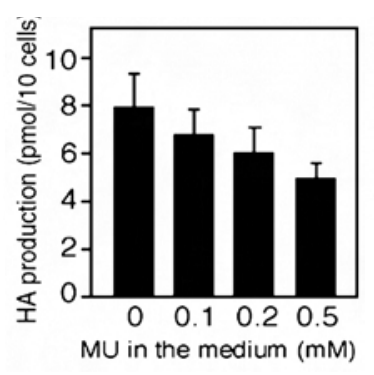

B16F10 cells. The number of cells that adhered to the culture dish decreased in the presence of MU in a dose-dependent manner. In contrast, the number of adhered cells in a hyaluronan-coated culture dish was increased (Fig. 5). Thus, it was demonstrated that when hyaluronan synthesis is inhibited by MU, adhesion of the B16F10 cells declines (15).
着する細胞の数を解析した。その結果、培養㿼に付着する細 胞の数は MU の濃度依存性に減少することを見出した。逆に、 ヒアルロン酸をコートした培養皿に細胞を撒いた場合、接着 する細胞数は増加していた(図 5)。すなわち、MUによりヒア ルロン酸の生合成が阻害されると B $16 \mathrm{~F} 10$ 細胞の接着能は低下 することを見出した(15)。
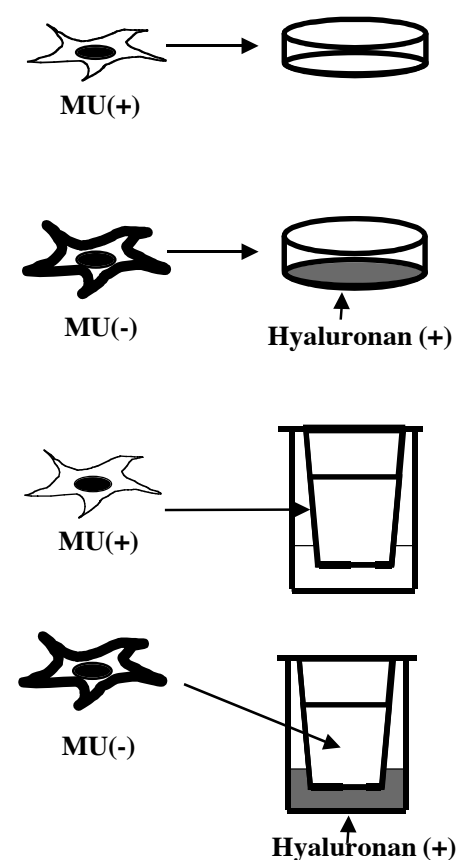

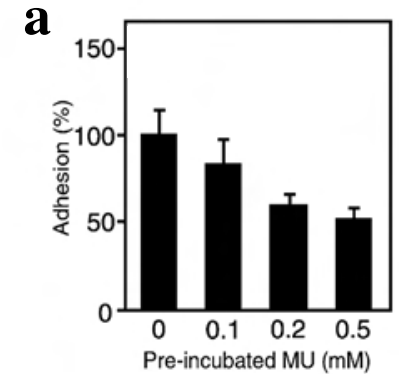

b

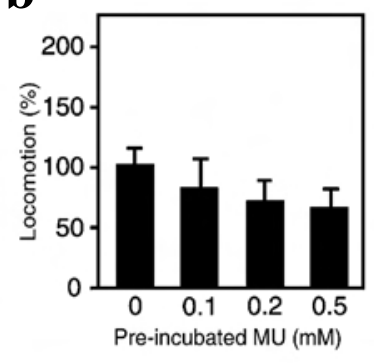

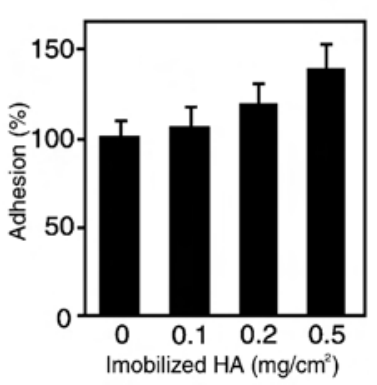

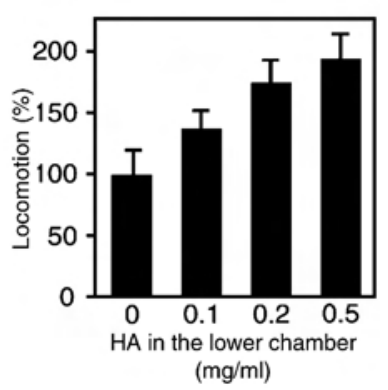

Fig. 5. Effect of MU on the adhesion and locomotion of melanoma cells. (a) B16F10 cells that had been pre-incubated with or without MU were added to a hyaluronan-coated or hyaluronan-uncoated culture dish and incubated for 20 min at $37^{\circ} \mathrm{C}$. The adherent cells were counted with a hematocytometer. The number of cells that adhered to the culture dish decreased in a MU dose-dependent manner. In contrast, the number of adhered cells in a hyaluronan-coated culture dish was increased. (B) The influence of MU on locomotion was investigated using the Boyden chamber method. The number of cells passing through from the upper chamber to the lower chamber was decreased in a dose-dependent manner in the presence of MU. On the other hand, when adding hyaluronan to the lower chamber, the number of cells that passed through was increased. 
We analyzed the effects of MU on cell locomotion using the Boyden chamber method. As a result of adding B16F10 cells treated with MU to the upper chamber to count the number of cells that passed through the filter membrane to the lower chamber, the number of cells passing through was decreased in a dose-dependent manner. On the other hand, when adding hyaluronan to the lower chamber, the number of cells that passed through was increased. Accordingly, we demonstrated that MU also suppresses locomotion (Fig. 5) (15).

The declines in adhesion and locomotion of the B16F10 cells caused by MU suggest that MU suppresses metastasis of the B16F10 cells. Therefore, we analyzed the effects of MU on the metastasis of B16F10 cells in mice. In this experiment, it was necessary to analyze the effects of MU on both hyaluronan synthesized by the B16F10 cells and hyaluronan synthesized by the organs to which the cells metastasized. Firstly, B16F10 cells that were treated with MU and had no hyaluronan on the cell surface were injected into mice via the tail vein. MU-untreated B16F10 cells were observed to metastasize to the liver and the lungs at a high frequency; however, metastasis was markedly suppressed in MU-treated B16F10 cells (Fig. 6) (36). Next, the B16F10 cells were injected into hyaluronan knockdown mice that had been orally administered MU in advance. In the control
細胞の遊走能に対する MU の効果を Boyden chamber 法 によって解析した。chamber 上層に MU 処理した B $16 \mathrm{~F} 10$ 細 胞を添加し、フィルター膜を通過して下層へと移動する細胞 の数を計測した結果、通過する細胞の数は MU の濃度依存性 に減少していた。一方、chamber下層にヒアルロン酸を添加 すると、通過する細胞の数は逆に増加した (図 5)。以上から、 MUは遊走能も抑制することを証明した (15)。

MUにより B16F10 細胞の接着能と遊走能が低下したこと は、MU が B16F10 細胞の転移を抑制する可能性を示唆してい る。そこで、生体マウスに打ける $\mathrm{B} 16 \mathrm{~F} 10$ 細胞の転移に対する MU の効果を解析した。この実験系では、B16F10 細胞が生合 成するヒアルロン酸と、転移する臟器が生合成するヒアルロ ン酸の両方が、MUによってどの様な影響を受けるか解析し なければならない。そこで、最初に、MU 処理して細胞表面 のヒアルロン酸が存在しない B $16 \mathrm{~F} 10$ 細胞をマウスの尾静脈か ら注入した。その結果、MU 未処理の B16F10 細胞は、肝臟や 肺に高率に転移したが、MU 処理した B16F10 細胞では転移が 著明に抑制されていた(図6) (36)。次に、ヒアルロン酸を予め 経口摂取させたマウス(ヒアルロン酸ノックダウンマウス)に

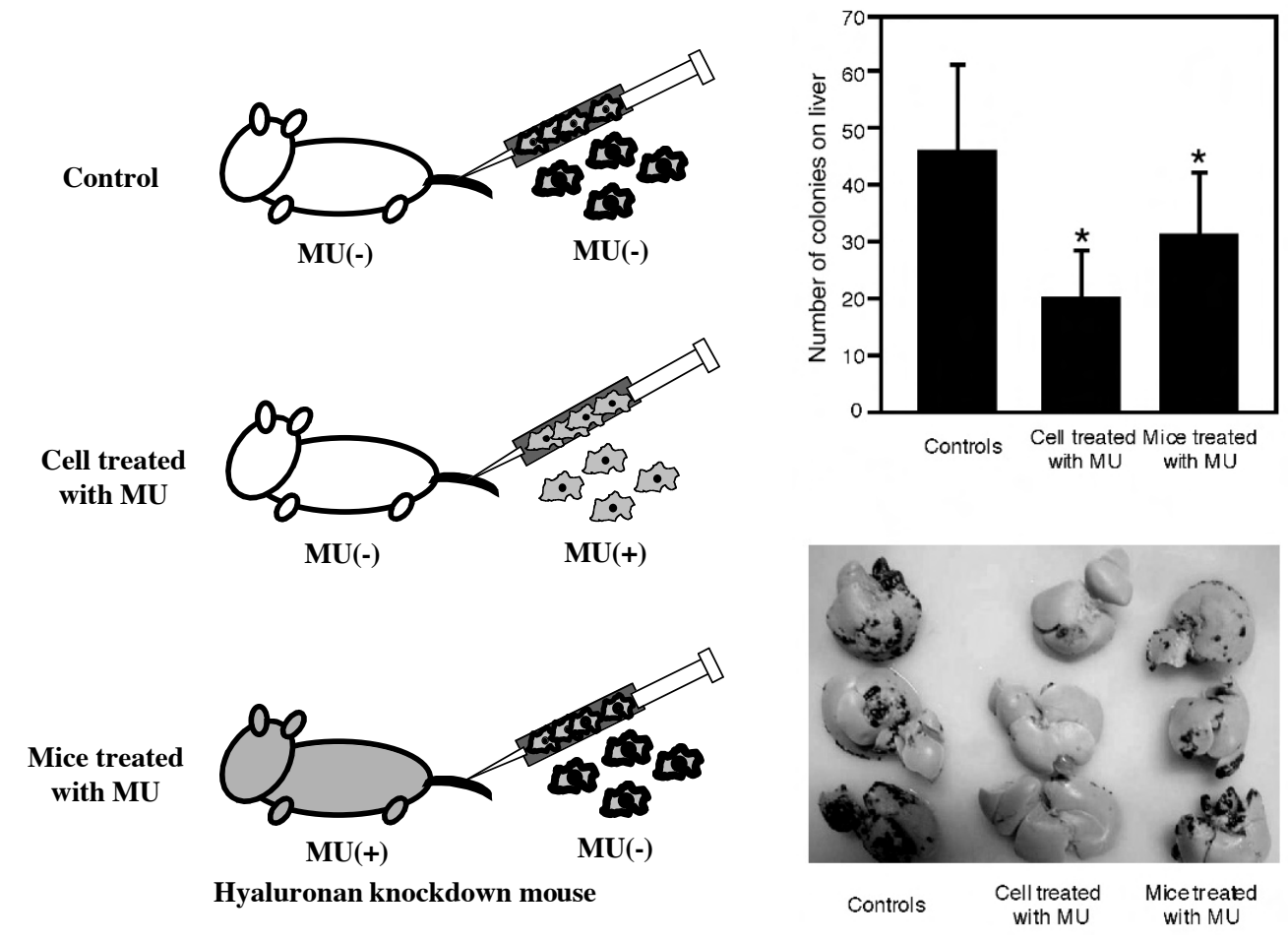

Fig. 6. Effect of MU on the formation of metastatic nodules on the liver. B16F10 cells that were treated with MU were injected into mice via the tail vein. The MU-untreated B16F10 cells metastasized to the liver at a high frequency, whereas metastasis of the MU-treated B16F10 cells was markedly suppressed. B16F10 cells were also injected into hyaluronan knockdown mice that had been orally administered MU. In the control mice, metastasis of the B16F10 cells was observed at a high rate, whereas metastasis in the MU-treated hyaluronan knockdown mice was markedly suppressed. 
mice, metastasis of the B16F10 cells was observed at a high rate, whereas it was markedly suppressed in the hyaluronan knockdown mice. Accordingly, hyaluronan in both the B16F10 cells and in the organs promoted metastasis, strongly indicating that MU could be a new anticancer agent (Fig. 6) (36).

We also analyzed the effects of MU on the metastasis of other types of malignant tumor such as pancreatic cancer, and demonstrated that MU can suppress the metastasis of any tumor $(37,38)$. MU is an agent that has frequently been used as a bile secretion promoter and its safety has been established. Therefore, it can be concluded that it is highly possible for MU to be orally administered as an anticancer agent to prevent the recurrence and metastasis of malignancies. In addition, we also analyzed the effects of various MU-derivatives for metastasis suppression and demonstrated that metastasis is a strongly suppressed by derivatives with more methyl groups and hydroxyl groups than $\mathrm{MU}(38,39)$.

Recently, several studies have reported that hyaluronan signals were blocked to treat malignant melanoma, and these reports have been drawing attention. Ahrens et al. reported that the hyaluronan receptor, CD44, is a mediator for proliferation and metastasis of malignant melanoma (40). Furthermore, it has been demonstrated that proliferation and metastasis of tumors can be suppressed by administering antiCD44 antibodies to the body, and the clinical application of this method has been rapidly promoted (41).

IL-2 therapy, in which IL-2 is administered to the body, is an extremely effective treatment for malignant melanoma. However, IL-2 therapy causes vascular leak syndrome (VLS), which can be fatal and cause multiple organ failure and shock (42). Guan et al. demonstrated that by administering the hyaluronan-specific binding protein Pep-1, which firmly binds to hyaluronan on the cell surface, to the body, it is possible to inhibit the interaction of hyaluronan with CD44, thereby suppressing metastasis of malignant melanomas (43). Furthermore, they found that Pep-1 administration also suppressed the onset of VLS and maintains the effects of IL-2 (43). In the future, it is expected that IL-2 therapy with the concomitant use of Pep- 1 can be a safe and highly effective treatment for malignant melanomas.

Malignant melanomas proliferate rapidly, metastasize easily, and have an extremely unfavorable clinical prognosis. One of the factors determining this prognosis is hyaluronan, and optimal regulation of hyaluronan expression will be a key for sustaining life. There are high expectations for the treatment effects of MU, anti-CD44 antibodies, and Pep-1, which are substances that suppress the expression of hyaluronan or hyaluronan signals, for malignant melanoma. In addition, anti-CD44 antibodies have already been clinically applied as a treatment agent. Accordingly, we believe that
B16F10 細胞を注入した。その結果、コントロールマウスでは 高率に B16F10 細胞の転移を認めたが、ヒアルロン酸ノックダ ウンマウスでは著明に転移が抑制された (図 6) (36)。以上から、 $\mathrm{B} 16 \mathrm{~F} 10$ 細胞及び藏器の両方のヒアルロン酸が転移を促進し、 しかも、MUが新規抗癌剤に成り得ることも示された。

我々は、膵臟癌など、他の悪性腫瘍の転移に対する $\mathrm{MU}$ の効果も解析し、何れの悪性腫瘍の転移に対しても抑制できる ことを証明した (37，38)。MU は胆汁排泄促進剤として広く使 用されている薬剤であり、その安全性は確立されている。従っ て、MU の経口投与が、悪性腫瘍の術後の再発や転移の予防 のための制癌剤として適応される可能性は非常に高いと考え られる。また、我々は、様々な MU 誘導体の転移抑制効果も 解析し、MUよりも多くのメチル基と水酸基を持つ誘導体に 強い転移抑制効果が存在することを証明 $(38,39)$ 、その臨床適 用の日は近いと期待されている。

最近、ヒアルロン酸のシグナルをブロックして悪性黒色腫 を治療する研究が幾つか報告され、注目されている。Ahrens らは、ヒアルロン酸レセプターCD44 が悪性黒色腫の増殖と 転移のメデイエーターであることを報告し (40)、抗 CD44 抗体 を生体内に投与すると、腫瘍の増殖と転移は抑制されること を証明、しかもその実用化が急速に進められている(41)。

IL-2 を生体内に投与する IL-2 療法も、悪性黒色腫に対す る非常に有効な治療法の一つである。しかし、IL-2 療法は、 多臟器不全やショックなどを引き起こして致死的となる毛細 血管漏出症候群 (vascular leak syndrome、VLS) が副作用とし て生じる (42)。Guan らは、細胞表面のヒアルロン酸に強く結 合する Hyaluronan-specific binding peptide (Pep-1) を生体内に 投与すると、ヒアルロン酸がCD44に結合することを阻害し、 その結果、悪性黒色腫の転移が抑制されることを証明した(43)。 しかも、Pep-1 の投与はVLS の発症も抑制し、かつ IL-2 の効 果を維持することを見出している (43)。今後、Pep-1を併用し た IL-2 療法は、悪性黒色腫のための安全且つ効果の高い治療 法になる可能性が期待される。

悪性黒色腫は急速に増殖し、容易に転移をして、臨床的な 予後は非常に悪い。この予後を決定づける因子の一つがヒア ルロン酸であり、いかにその発現を制御できるかが延命の鍵 となる。上で述べた MU、抗 CD44 抗体、Pep-1 はヒアルロン 酸の発現やヒアルロン酸シグナルを制御する物質として同定 され、その治療効果は十分に期待できる。しかも抗 CD44 抗 体は治療薬として既に臨床適用され始めている。従って、今後、 これらの物質の至適な投与方法が確立されれば、悪性黒色腫 
in the future, if optimal methods of administration of these substances are established, the treatment outcomes for malignant melanomas will improve dramatically.

\section{F. Comments}

When asked "What is the role of hyaluronan in the skin?" in the past, the answer would have been "To prevent dryness of the skin." It has now been revealed that hyaluronan is an important substance that regulates various mechanisms such as skin development, differentiation, regeneration, aging/ anti-aging, and carcinogenesis. However, these studies have only just begun, and as shown in this study, the details are still unknown. Accordingly, it is necessary to clarify the molecular mechanisms, which is an urgent task for clinical medicine. If it becomes possible to freely regulate the expression of hyaluronan in the skin in future, it would be possible to maintain skin that is forever young, beautiful, and sturdy, as well as skin that does not develop malignancies. This is important for general health because the skin is essential for maintaining general homeostasis and it is impossible for humans to live without the skin. For such reasons, we believe that it is necessary to promote further studies on hyaluronan.
の治療成績は飛躍的に向上すると期待される。

F. おわりに

「皮膚に打けるヒアルロン酸の役割は何か?」と尋ねられ れば、以前、その答えは「皮膚の乾燥を防ぐ」くらいであっ た。しかし今やヒアルロン酸は皮膚の発生、分化、再生、老 化/アンチエイジング、癌化など様々な機構を制御する重要 な物質であることが明らかになった。しかし、これらの研究 は未だ始まったばかりであり、この総説からも解るように詳 細は不明である。従って、その分子機構を解き明かすことは 必要であり、臨床医学的にも急務なことである。将来、皮膚 に打けるヒアルロン酸の発現を自由自在に制御することが可 能になれば、いつまでも若々しく、美しく、丈夫な皮膚、そ し悪性腫瘍の発生しない皮膚を維持できるようになる。そし てこのことは、皮膚が全身のホメオスタシスの維持にとって 必要不可欠で、皮膚無くして生存することは不可能であるこ とから、全身の健康にとっても重要なことである。そのため にも、いま皮膚のヒアルロン酸研究を推進させることが必要 であると言える。

\section{References}

1. Toole, B. P. (2004) Nat. Rev. Cancer. 4, 528-539.

2. Tammi, R. H., and Tammi, M. I. (2009) J. Invest. Dermatol. 129, 1858-1860.

3. Tammi, R. H., Kultti, A., Kosma, V. M., Pirinen, R., Auvinen, P., and Tammi, M. I. (2008) Semin. Cancer Biol. 18, $288-295$.

4. Stern, R., and Maibach, H. I. (2008) Clin. Dermatol. 26, 106-122.

5. Itano, N., Zhuo, L., and Kimata, K. (2008) Cancer Sci. 99, 1720-1705.

6. Itano, N., and Kimata, K. (2008) Semin. Cancer Biol. 18, 268-274.

7. Weissman, B., and Meyer, K. J. (1954) Am. Chem. Soc. 76, 1753-1757.

8. Reed, R. K., Lilja, K., and Laurent, T. C. (1988) Acta. Physiol. Scand. 134, 405-411.

9. Laurent, T. C., and Fraser, J. R. (1992) FASEB J. 6, 2397-2404.

10. Itano, N., and Kimata, K. (1996) J. Biol. Chem. 271, 9875-9878.

11. Weigel, P. H., Hascall, V. C., and Tammi, M. J. (1997) J. Biol. Chem. 272, 13997-14000.

12. Spicer, A. P., Kaback, L. A., Smith, T. J., and Seldin, M. F. (1998) J. Biol. Chem. 273, 25117- 25124.

13. Itano, N., and Kimata, K. (2002) IUBMB Life. 54, 195-199.

14. Knudson, C. B., and Knudson, W. (1993) FASEB J. 7, 1233-1241.

15. Kudo, D., Kon, A., Yoshihara, S., Kakizaki, I., Sasaki, M., Endo, M. and Takagaki, K. (2004) Biochem. Biophys. Res. Commun. 321, 783787.

16. Hess A. (1954) Anat. Rec. 119, 435-447.

17. Ihara, S., Motobayashi, Y., Nagao, E., and Kistler, A. (1990) Development 110, 671-680.

18. Kishi, K. (2003) J. Ther. 85, 2767-2771.

19. Lorenz, H. P., Whitby, D. J., Longaker, M. Y., Adzick, N. S. (1993) Ann. Surg. 217, 391-396.

20. Estes, J. M., Adzick, N. S., Harrison, M. R., Longaker, M. T., and Stern, R. (1993) J. Pediatr. Surg. 28, $1227-1231$.

21. Iocono, J. A., Ehrlich, H. P., Keefer, K. A., and Krummel, T. M. (1998) J. Pediatr. Surg. 33, 564-567.

22. Mast, B. A., Haynes, J. H., Krummel, T. M., Diegelmann, R. F., and Cohen, I. K. (1992) Plast. Reconstr. Surg. 89, $503-509$.

23. Kennedy, C. I., Diegelmann, R. F., Haynes, J. H., and Yager, D. R. (2000) J. Pediatr. Surg. 35 874-879.

24. Olutoye, O. O., Barone, E. J., Yager, D. R., Uchida, T., Cohen, I. K., and Diegelmann, R. F. (1997) J. Pediatr. Surg. 32, $1037-1040$.

25. Chin, G. S., Stelnicki, E. J., Gittes, G. K., and Longaker, M. Y. (2000) in Scarless Wound Healing, pp.239-262, Mercel Decker, NewYork.

26. Stelnicki, E. J., Arbeit, J., Cass, D. L., Saner, C., Harrison, M., and Largman, C. (1998) J. Invest. Dermatol. $111,57-63$.

27. Mack, J. A., Abramson, S. R., Ben, Y., Coffin, J. C., Rothrock, J. K., Maytin, E. V., Hascall, V. C., Largman, C., and Stelnicki, E. J. (2003) FASEB J. 17, 1352-1354.

28. Fisher, G. J., Kang, S., Varani, J., Bata-Csorgo, Z., Wan, Y., Datta, S., and Voorhees, J. J. (2002) Arch. Dermatol. $138,1462-1470$.

29. Moriwaki, S., and Takahashi, Y. J. (2007) J. Dermatol. Sci. 50, 169-176.

30. Averbeck, M., Gebhardt, C. A., Voigt, S., Beilharz, S., Anderegg, U., Termeer, C. C., Sleeman, J. P., and Simon, J. C. (2007) J. Invest. Der- 
matol. 127, 687-697.

31. Calikoglu, E., Sorg, O., Tran, C., Grand, D., Carraux, P., Saurat, J. H., and Kaya, G. (2006) Photochem. Photobiol. 82, $1342-1347$.

32. Dai, G., Freudenberger, T., Zipper, P., Melchior, A., Grether-Beck, S., Rabausch, B., de Groot, J., Twarock, S., Hanenberg, H., Homey, B., Krutmann, J., Reifenberger, J., and Fischer, J. W. (2007) Am. J. Pathol. 171, 1451-1461.

33. Nakamura, T., Funahashi, M., Takagaki, K., Munakata, H., Tanaka, K., Saito, Y., and Endo, M. (1997) Biochem. Mol. Biol. Int. 43, 263268.

34. Kakizaki, I., Takagaki, K., Endo, Y., Kudo, D., Ikeya, H., Miyoshi, T., Baggenstoss, B. A., Tlapak-Simmons. V. L., Kumari, K., Nakane, A., Weigel, P. H., and Endo, M. (2002) Eur. J. Biochem. 269, 5066-5075.

35. Kakizaki, I., Kojima, K., Takagaki, K., Endo, M., Kannagi, R., Ito, M., Maruo, Y., Sato, H., Yasuda, T, Mita, S., Kimata, K., and Itano N. (2004) J. Biol. Chem. 279, 33281-33289.

36. Yoshihara, S., Kon, A., Kudo, D., Nakazawa, H., Kakizaki I., Sasaki M., Endo, M., and Takagaki, K. (2005) FEBS Lett. 579, $2722-2726$.

37. Nakazawa, H., Yoshihara, S., Kudo, D., Morohashi, H., Kakizaki, I., Kon, A., Takagaki, K., and Sasaki, M. (2006) Cancer Chemother. Pharmacol.57. 165-170.

38. Morohashi, H., Yoshihara, S., Nakai, M., Nakazawa, H., Yamaguchi, Y., Kakizaki, I., Kon, A., Sasaki, M., and Takagaki, K. (2007) Int. J. Cancer 120, 2704-2709.

39. Morohashi, H., Kon, A., Nakai, M., Yamaguchi, M., Kakizaki, I., Yoshihara, S., Sasaki, M., and Takagaki, K. (2006) Biochem. Biophys. Res. Commun. 345, 1454-1459.

40. Ahrens, T., Assmann, V., Fieber, C., Termeer, C., Herrlich, P., Hofmann, M., and Simon, J. C. (2001) J. Invest. Dermatol. 116, 93-101.

41. Platt, V. M., and Szoka, F. C Jr. (2008) Mol. Pharm. 5, 474-486.

42. Chelstrom, L. M., Finnegan, D., and Uckun, F. M. (1992) Leuk. Lymphoma. 7, 79-86.

43. Guan, H., Nagarkatti, P. S., and Nagarkatti, M. (2007) J. Immunol. 179, 3715-3723.

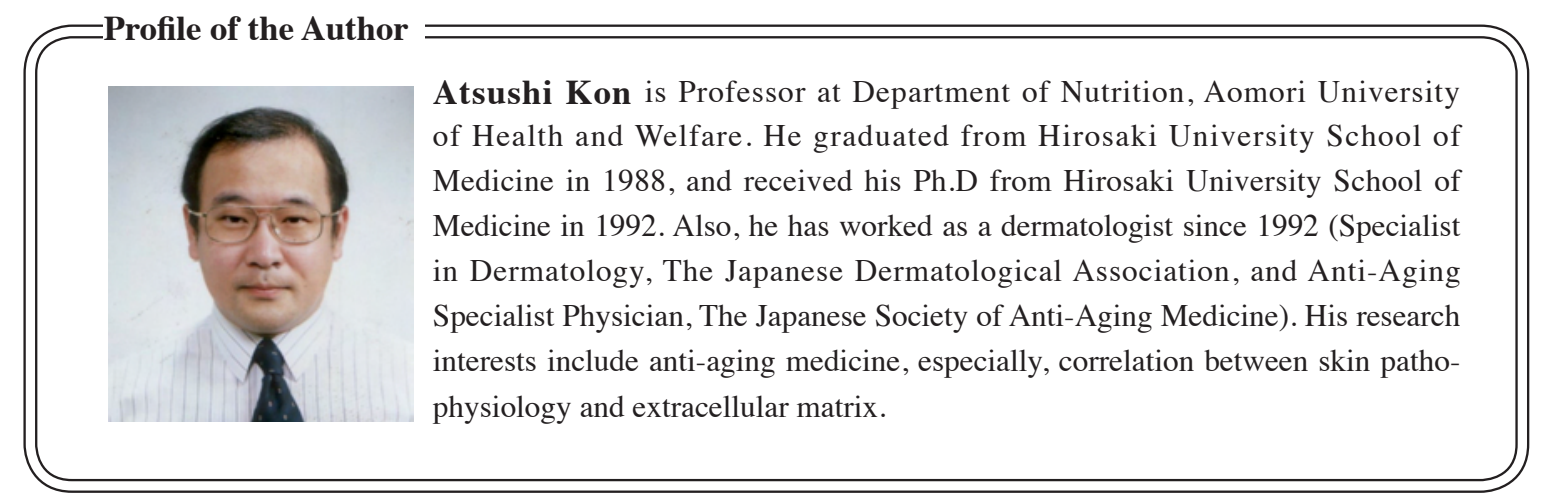

